\title{
INTERACTION OF Meloidogyne incognita AND Fusarium oxysporum IN CARNATION AND PHYSIOLOGICAL CHANGES INDUCED IN PLANTS DUE TO THE INTERACTION
}

\author{
K. Sankari Meena ${ }^{1 *}$, S. A. Ramyabharathi ${ }^{2}$, T.Raguchander ${ }^{2}$ \\ and E. I. Jonathan ${ }^{1}$ \\ ${ }^{1}$ Department of Nematology, Tamil Nadu Agricultural University, \\ Coimbatore 641 003, Tamil Nadu, India \\ ${ }^{2}$ Department of Plant Pathology,' Tamil Nadu Agricultural University, \\ Coimbatore 641 003, Tamil Nadu, India
}

\begin{abstract}
Two pot culture experiments were carried out in carnation var. redking in two different seasons to study the interactive effect of Fusarium oxysporum and Meloidogyne incognita on the growth, yield and changes in physiological parameters of the plant. Highest reduction of growth and yield parameters were observed in the plants that received sequential inoculation of the nematode followed by fungus. Significant reduction in the nematode population was observed in the sequential inoculation of the fungus followed by nematodes and combined inoculation of the two pathogens. Reduced chlorophyll content and increased protein and sugar content were observed in the plants due to the interaction of nematode and fungus.
\end{abstract}

Keywords: Chlorophyll, fungus, interaction, nematode, plant growth, protein, sugar content, wilt incidence

\section{INTRODUCTION}

Carnation (Dianthus caryophyllus L.) is the second most popular flower in the world next to rose (Mahalakshmi and Raja, 2013). Attractive colors of the flowers make them to fetch an important position in export industries. Owing to the increasing demand of the flowers in the market, production of this crop has been increased in recent years. Potential of the crop in the production of effective flowers has been declined due to various limitations. It includes several biotic and abiotic stresses among which infestation of fungus and nematodes are ranked as the predominant biotic factors involved in reducing the yield of the crop substantially.

\footnotetext{
*Corresponding author email: meenaa5@rediffmail.com
}

Received: 25.02.2016 
Combined infection of nematodes and fungus cause severe quantitative and qualitative loss to the plants than their individual infection. It is a well known fact that nematodes predispose the plants to the secondary invasion by the fungal pathogens and aggravate the disease severity by modification of the plant roots (Mai and Abawi, 1987). Disease complex of nematodes with other organisms disrupt the ability of the plants to take up water and other nutrients from soil which reduce the vigour of the plants and ultimately to death of the plants (Masse et al., 2002). Infection of these two pathogens causes measurable changes in the physiology of the host. They reduced photosynthetic rate and inturn increased protein and sugar level in the plants which serve as nutrient source for the pathogens. Interactive effect of fungus and nematodes has been documented earlier in various crops like banana (Jonathan and Gajendran, 1998), chickpea (Maria et al., 1998), crossandra (Mallaiah et al., 2014) and gerbera (Sankari Meena et al., 2015).

Present investigation has been carried out to study the interactive effect of Fusarium oxysporum and Meloidogyne incognita in carnation with reference to different time of inoculation of the two pathogens and the associated physiological changes taking place due to their infection with reference to chlorophyll content, total proteins and total sugars.

\section{MATERIALS AND METHODS}

\section{Identification of Meloidogyne species associated with carnation}

Root knot nematode culture was obtained from the nematode infected carnation field at Nilgiris District, Tamil Nadu, India. Galled roots of the plants were collected and washed in tap water to remove the adhering soil particles and the galls were excised to collect the protruding egg mass under stereo microscope (CETI-STEDDY$\mathrm{T} 7300.0000$, UK). The collected egg masses were placed in distilled water for hatching. After 24-48 h, the entire eggs were hatched into juveniles and the freshly hatched juveniles were used for the interaction studies.

Root knot nematode females collected from the roots were processed for perineal pattern observation to confirm the nematode species associated with the crop. Matured Meloidogyne females were teased from the root galls and placed on a glass slide. They were cut at the neck region and body tissues were gently pushed out. The cuticle was placed in $45 \%$ lactic acid to facilitate further cleaning. The cuticle was carefully trimmed so that 5-10 times the perineal area (area near to vulva) was retained. This was transferred to a fresh drop of glycerol and examined under microscope.

\section{Identification of Fusarium species associated with carnation}

Inoculum of Fusarium was obtained from the wilt infected carnation plants collected at Nilgiris district, Tamil Nadu, India. For the isolation of Fusarium species, a small section of the infected root $(5-6 \mathrm{~mm})$ tissues were cut and placed on 
Potato Dextrose Agar (PDA) medium with an antibacterial agent (Streptomycin sulfate). The plate was incubated for 2-4 days. Conidial culture prepared from the specimen was used for the interaction studies.

Fusarium species associated with the crop was identified by the observation of conidial characters. Sporulated hyphae was scrapped from the PDA medium and placed over a cavity slide. Few drops of water was added to the slide and mixed well with the hyphae. The slide was checked under microscope (CETI-STEDDY-T $7300.0000, \mathrm{UK})$ to observe the conidial characters.

\section{Interaction studies of nematode-fungus in carnation}

Tissue culture plants of carnation var. redking were obtained from Florence and Flora, Bangalore and used for the pot culture studies. Pot culture experiments were carried out during July to August 2014 and October to November, 2014 in the green house of Tamil Nadu Agricultural University, Coimbatore, India maintaining the temperature of $28 \pm 2^{\circ} \mathrm{C}$.

About 25 days old plants were planted in $5 \mathrm{~kg}$ pots filled with sterilized pot mixture (red soil: sand:FYM-2:1:1). After the establishment of plants in the pots, nematodes and fungus were inoculated into the pots with the treatment as mentioned in table 1 . Nematodes were inoculated at one $\mathrm{J}_{2} / \mathrm{g}$ soil and fungus as $50 \mathrm{ml}$ conidial suspension (1000 conidia/ml) per pot. All the treatments were imposed in the rhizosphere region of the plants. Each treatment was replicated five times in completely randomized design.

Experiments were terminated 30 days after inoculation of the treatments and the plants were observed for their growth and yield characters. Per cent wilt incidence due to fungus was assessed by counting the number of wilt infected plants /total number of plants taken for observation. The plant roots were observed for number of galls present per root system.

Roots were stained for the observation of nematode females and egg mass present per root system. For staining, roots were washed in tap water to remove the adhering soil particles and then plunged into warm $\left(80^{\circ} \mathrm{C}\right)$ acid fuchsin lactophenol for 1 to 2 minutes. Excess stains in the roots were removed by washing in water and the roots were transferred to plain lactophenol (lactic acid 20ml; liquid phenol 20ml; glycerine $40 \mathrm{ml}$; distilled water $20 \mathrm{ml}$ ) to clear the plant tissues. After $24 \mathrm{~h}$, the roots were observed under microscope to count the number of females and egg mass present in the roots. Nematode population in the soil was processed as per the sieving method of Cobb and Modified Baermann funnel technique.

\section{Estimation of physiological changes in the plants due to nematode fungus interaction}

Fresh leaves were collected from the plants at the time of termination of the experiment to observe the quantitative changes in chlorophyll, total proteins and total sugar contents in the plants due to interaction. 


\section{(i). Estimation of chlorophyll content}

About one $\mathrm{g}$ fresh leaf tissue of the plants was ground with liquid nitrogen in a pestle and mortar to fine powder. One $\mathrm{ml}$ of $85 \%$ acetone $(\mathrm{pH} 8)$ was added and ground further. The suspension was poured into a $1.5 \mathrm{ml}$ tube and centrifuged at $10,000 \mathrm{rpm}$ for 3 minutes. One $\mathrm{ml}$ of supernatant was taken and it was diluted to $3 \mathrm{ml}$ with $85 \%$ acetone and absorbance was read in a spectrophotometer at 645 and 663 $\mathrm{nm}$ for chlorophyll $\mathrm{a}$ and $\mathrm{b}$. If absorbance was greater than 1.0, the solution was further diluted with acetone. The amount of chlorophyll content was expressed as $\mathrm{mg}$ $\mathrm{g}^{-1}$ fresh weight.

\section{(ii). Estimation of total protein}

About $0.5 \mathrm{~g}$ of fresh leaves were immersed in hot $80 \%$ ethanol seperately for 5 minutes and ethanol was removed and the leaf tissue was crushed with $10 \mathrm{ml}$ of $5 \%$ trichloroacetic acid (TCA) and centrifuged for $5 \mathrm{~min}$. The tissues were washed separately in $5 \mathrm{ml}$ of absolute ethanol, ethanol-chloroform mixture $(3: 1, \mathrm{v}: \mathrm{v})$ and ethanol-ether mixture $(3: 1 \mathrm{v}: \mathrm{v})$. The washed residues were then incubated in $5 \mathrm{ml}$ of $0.5 \mathrm{~N} \mathrm{NaOH}$ for $16 \mathrm{~h}$ at $37^{\circ} \mathrm{C}$. The sediment was removed by centrifuging and washed with $5 \mathrm{ml}$ of $0.5 \mathrm{~N} \mathrm{NaOH}$. The extract and wash were combined and $0.5 \mathrm{~N}$ $\mathrm{NaOH}$ was added to make up the volume to $10 \mathrm{ml}$. Two $\mathrm{ml}$ of extract were taken from it to determine the protein content. Total protein was estimated following the method of Bradford (1976) and the results were expressed as $\mathrm{mg} \mathrm{g}^{-1}$ fresh weight.

\section{(iii). Estimation of total soluble sugar}

About $0.5 \mathrm{~g}$ of fresh leaves were separately homogenized with $10 \mathrm{ml}$ of $80 \%$ ethanol. After centrifugation at $2000 \mathrm{rpm}$ for $15-20 \mathrm{~min}$, the supernatant was collected. To this $1 \mathrm{ml}$ of alcoholic extract, $1 \mathrm{ml}$ of $5 \%$ phenol solution was added. Then $5 \mathrm{ml}$ of $96 \%$ sulphuric acid was added by gentle agitation and then allowed to stand in a water bath at $25-30^{\circ} \mathrm{C}$ for $2 \mathrm{~min}$. Optical density (OD) values were measured at $490 \mathrm{~nm}$ and a standard graph was prepared by using known concentration of glucose. Amount of sugar was expressed in $\mathrm{mg} \mathrm{g}^{-1}$.

\section{Statistical analysis}

The study was performed over two seasons with the same set of treatments and replication. Treatment effects were found to be consistent among the two seasons, thus data collected over the two seasons in the pot culture studies were pooled and subjected to analysis of variance (ANOVA) according to Gomez and Gomez (1984). After ANOVA, Fisher's least significant difference (LSD) tests were performed (Sokal and Rohlf, 1995).

\section{RESULTS}

\section{Identification of Meloidogyne species associated with carnation}

Meloidogyne species collected from carnation roots were identified by their cuticular markings in the perenial area of the matured female (Figure 1a). The nematode species observed were with high dorsal arch which were flattened at the top (Figure 1b) which confirmed the nematode as Meloidogyne incognita. 


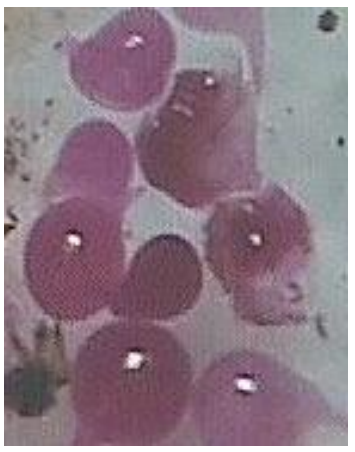

a. Stained females

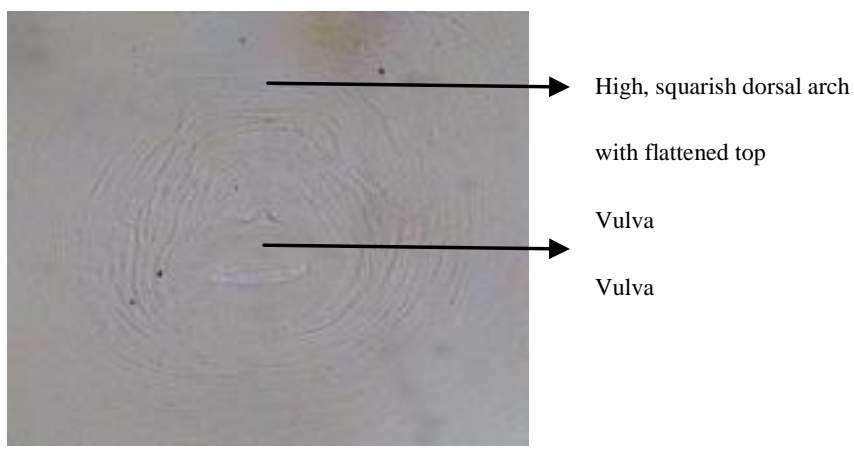

b. Perineal pattern of the root knot nematode female

Figure 1. Root knot nematode species associated with carnation var. red king

\section{Identification of Fusarium species associated with carnation}

Fusarium species was identified based on the morphological characters. The microscopic study revealed small, oval shaped, single or bicelled microconidia. Hyaline, multicelled macroconidia with 3 septation which were sickle shaped with knotched base at one end which revealed the species as $F$. oxysporum (Figure 2).

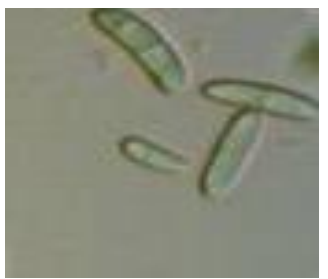

Microconidia

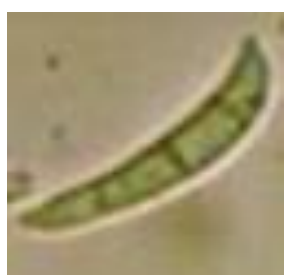

Macroconidia

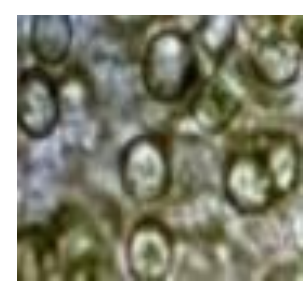

Chlamydospores

Figure 2. Fusarium species associated with carnation var. red king

\section{Effect of interaction on growth and yield parameters of carnation}

Nematode and fungus infestation decreased the growth and yield parameters of the plant compared to uninoculated control. Among different treatments, inoculation of nematodes 15 days prior to fungus recorded the least growth parameters of the plant (shoot length: $56.23 \mathrm{~cm}$; root length: $14.73 \mathrm{~cm}$; shoot weight: $28.93 \mathrm{~g}$ and root weight: $2.10 \mathrm{~g}$ ) followed by the combined application of nematode and fungus. Highest growth parameters were observed in uninoculated control plants (shoot length: $82.73 \mathrm{~cm}$; root length: $40.40 \mathrm{~cm}$; shoot weight: $37.70 \mathrm{~g}$ and root weight: $6.10 \mathrm{~g})$. Regarding flower yield, significant reduction in the number of flowers $(0.50)$ with reduced stalk length $(56.25 \mathrm{~cm})$ and flower diameter $(5.40 \mathrm{~cm})$ were observed in the plants that received inoculation of nematodes 15 days prior to fungus while the 
above parameters were found to be highest in the uninoculated control plants which recorded 1.50 flowers, with increased stalk length $(67.75 \mathrm{~cm})$ and flower diameter $(7.18 \mathrm{~cm})($ Table 1$)$.

Table 1. Effect of $M$. incognita and F. oxysporum interaction on growth and yield of carnation var. red king*

\begin{tabular}{|c|c|c|c|c|c|c|c|}
\hline \multirow{3}{*}{ Treatments } & \multicolumn{4}{|c|}{ Growth parameters } & \multicolumn{3}{|c|}{ Yield parameters } \\
\hline & \multicolumn{2}{|c|}{ Shoot } & \multicolumn{2}{|r|}{ Root } & \multirow{2}{*}{$\begin{array}{c}\text { Stalk } \\
\text { length } \\
(\mathrm{cm})\end{array}$} & \multirow{2}{*}{$\begin{array}{l}\text { Flower } \\
\text { diameter } \\
(\mathrm{cm})\end{array}$} & \multirow{2}{*}{$\begin{array}{c}\text { No. of } \\
\text { flowers/pl } \\
\text { ant }\end{array}$} \\
\hline & $\begin{array}{l}\text { length } \\
(\mathrm{cm})\end{array}$ & $\begin{array}{l}\text { weight } \\
(\mathrm{g})\end{array}$ & $\begin{array}{c}\text { length } \\
(\mathrm{cm})\end{array}$ & $\begin{array}{l}\text { weight } \\
(\mathrm{g})\end{array}$ & & & \\
\hline Nematode alone $(\mathrm{N})$ & 72.93 & 30.75 & 34.88 & 5.60 & 60.00 & 5.88 & 1.00 \\
\hline Fungus alone $(\mathrm{F})$ & 74.45 & 31.13 & 36.58 & 5.66 & 60.25 & 6.00 & 1.00 \\
\hline $\begin{array}{l}\text { Concomitant } \\
\text { inoculation of } \\
\text { nematode and fungus } \\
(\mathrm{N}+\mathrm{F})\end{array}$ & 64.58 & 28.73 & 18.70 & 2.50 & 59.25 & 5.65 & 0.75 \\
\hline $\begin{array}{l}\mathrm{N} 15 \text { days prior to } \mathrm{F} \\
\text { inoculation }\end{array}$ & 56.23 & 28.93 & 14.73 & 2.10 & 56.25 & 5.40 & 0.50 \\
\hline $\begin{array}{l}\text { F } 15 \text { days prior to } \mathrm{N} \\
\text { inoculation }\end{array}$ & 67.20 & 30.50 & 28.10 & 5.50 & 59.75 & 5.80 & 0.75 \\
\hline Uninoculated control & 82.73 & 37.30 & 40.40 & 6.10 & 67.75 & 7.18 & 1.50 \\
\hline SEd & 1.20 & 3.14 & 0.65 & 0.36 & 1.12 & 0.13 & 0.31 \\
\hline $\mathrm{CD}(0.05)$ & 2.54 & 6.60 & 1.37 & 0.76 & 2.36 & 0.27 & 0.65 \\
\hline
\end{tabular}

*Pooled data of two pot culture experiments conducted during July to August 2014 and October to November, 2014

\section{Effect of interaction on nematode population and fungus colonies in carnation}

Highest nematode population in the soil $(375 / 250 \mathrm{cc}$ soil) and root (76 females/g root) with maximum gall index (5) was observed in the plants that received nematode treatment alone. Similarly, wilt incidence of $73 \%$ was observed in roots that received fungus treatment alone. Plants that received inoculation of nematodes 15 days prior to fungus recorded maximum wilt incidence due to fungus (92.75) with the nematode population of 320/250 cc soil and 73.75 females/ g root. Sequential inoculation of nematodes followed by fungus and combined application of the two pathogens suppressed the nematode population in the roots significantly over other treatments by preventing the entry of the nematodes into the roots due to the formation of mycelia mat around the roots (Table 2). 
Table 2. Effect of $M$. incognita and $F$. oxysporum interaction on nematode population and per cent wilt incidence in carnation var. red king*

\begin{tabular}{l|c|c|c|c|c}
\hline \multirow{3}{*}{ Treatments } & \multicolumn{4}{|c|}{ Nematode population } & \multirow{2}{*}{} \\
\cline { 2 - 5 } & \multicolumn{3}{|c|}{ Root population } & Soil population & \multirow{2}{*}{$\begin{array}{c}\text { Per cent wilt } \\
\text { incidence }\end{array}$} \\
\cline { 2 - 5 } & $\begin{array}{c}\text { No. of } \\
\text { females/g } \\
\text { root }\end{array}$ & $\begin{array}{c}\text { No. of egg } \\
\text { mass/ } \\
\text { g root }\end{array}$ & $\begin{array}{c}\text { Gall index } \\
(0-5 \text { scale) }\end{array}$ & $\begin{array}{c}\text { No. of } \\
\text { juveniles/ } \\
250 \text { cc soil }\end{array}$ & \\
\hline Nematode alone (N) & 76.00 & 63.75 & 5.00 & 375.00 & 4.75 \\
Fungus alone (F) & $(9.05)$ & $(8.06)$ & $(2.23)$ & $(19.10)$ & $(14.17)$ \\
Concomitant inoculation of & 0.00 & 0.00 & 0.00 & 0.00 & 73.00 \\
nematode and fungus (N+F) & $(0.70)$ & $(0.70)$ & $(0.70)$ & $(0.70)$ & $(59.34)$ \\
N 15 days prior to F & 72.25 & 52.00 & 3.00 & 280.00 & 77.75 \\
inoculation & $(8.60)$ & $(7.48)$ & $(1.73)$ & $(16.76)$ & $(64.89)$ \\
F 15 days prior to N inoculation & 73.75 & 63.50 & 4.50 & 320.00 & 92.75 \\
& $(8.83)$ & $(7.87)$ & $(2.00)$ & $(17.97)$ & $(73.57)$ \\
Uninoculated control & 63.75 & 52.00 & 2.75 & 250.00 & 72.75 \\
& $(8.06)$ & $(7.14)$ & $(1.41)$ & $(16.27)$ & $(57.41)$ \\
SEd & 0.00 & 0.00 & 0.00 & 0.00 & 0.00 \\
CD (0.05) & $(0.70)$ & $(0.70)$ & $(0.70)$ & $(0.70)$ & $(2.86)$ \\
\hline
\end{tabular}

*Pooled data of two pot culture experiments conducted during July to August 2014 and October to November, 2014

Gall index: $1=$ No galls; $2=1-25 \%$ galls; $3=26-50 \%$ galls; $4=51-75 \%$ galls; $5=76-100 \%$ galls per root system. Figures in parenthesis are square root of $x+0.5$ transformed values for nematode population and arcsine transformed values for wilt incidence

\section{Effect of interaction on the physiological changes in the plant}

Nematode and fungus infection significantly reduced chlorophyll $a, b$, total chlorophyll and protein content in the plant leaves. Among different treatments, significant reduction in the chlorophyll a $\left(0.382 \mathrm{mg} \mathrm{g}^{-1}\right), \mathrm{b}\left(0.234 \mathrm{mg} \mathrm{g}^{-1}\right)$ and total chlorophyll $\left(0.616 \mathrm{mg} \mathrm{g}^{-1}\right)$ contents were observed when nematodes were inoculated 15 days prior to fungus while uninoculated control plants recorded the highest chlorophyll a $\left(0.784 \mathrm{mg} \mathrm{g}^{-1}\right), \mathrm{b}\left(0.506 \mathrm{mg} \mathrm{g}^{-1}\right)$ and total chlorophyll $\left(1.291 \mathrm{mg} \mathrm{g}^{-1}\right)$ contents. Increased level of proteins and soluble sugars were recorded due to the interaction of the two pathogens in the plants. Significant increase in protein contents $\left(5.328 \mathrm{mg} \mathrm{g}^{-1}\right)$ were observed when nematodes were inoculated 15 days prior to fungus followed by the concomitant inoculation of the two pathogens $\left(4.970 \mathrm{mg} \mathrm{g}^{-1}\right)$ while untreated control recorded the protein content of $4.603 \mathrm{mg} \mathrm{g}^{-1}$. Plants that received nematode inoculation 15 days prior to the fungus recorded increased level of soluble sugars in the plants which accounted for $2.243 \mathrm{mg} \mathrm{g}^{-1}$ while untreated control 
recorded the sugar level of $1.850 \mathrm{mg} \mathrm{g}^{-1}$ (Table 3).

Table 3. Effect of $M$. incognita and $F$. oxysporum interaction on the physiological changes in the plants

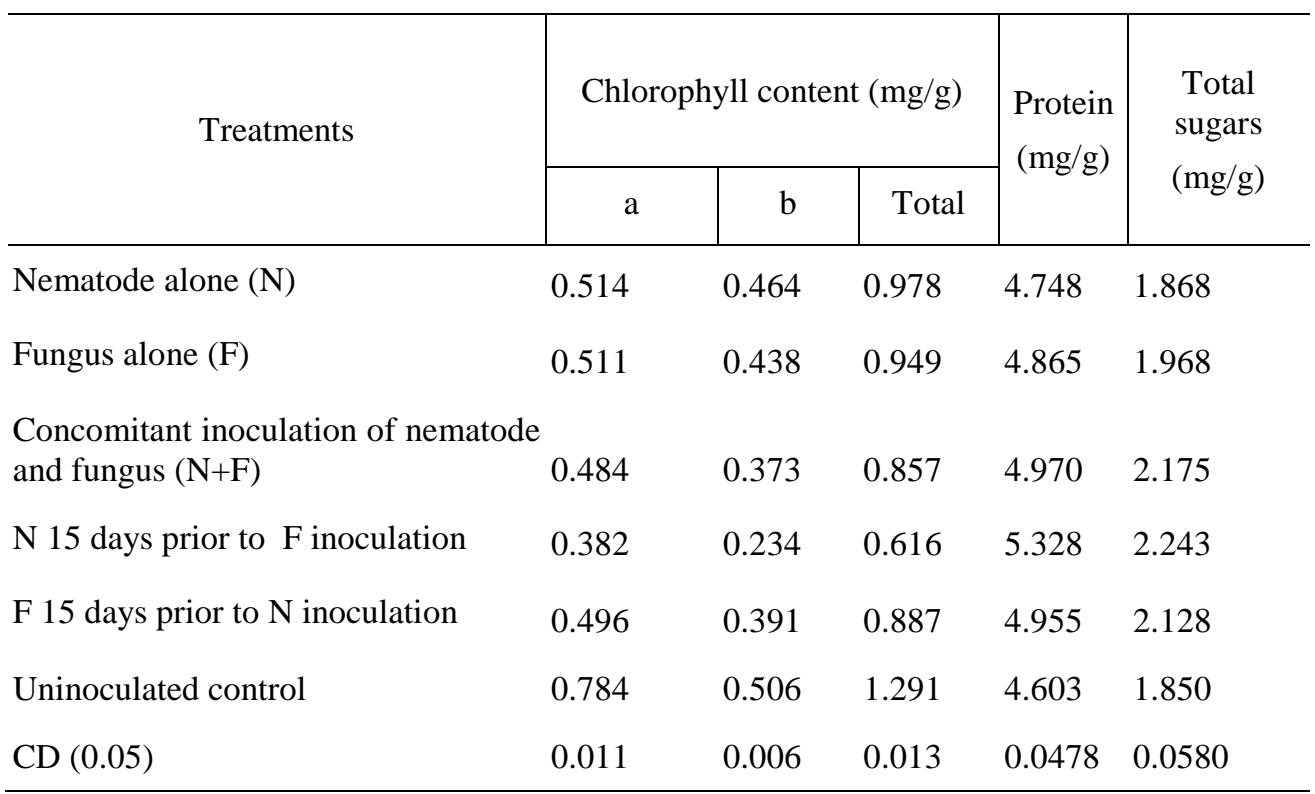

*Pooled data of two pot culture experiments conducted during July to August 2014 and October to November 2014

\section{DISCUSSION}

Combined or sequential infection of nematode and fungus cause synergistic effect in crop plants than their individual infection. Though this phenomenon is common in almost all the crops, only few reports were evidenced for the study. Infection of nematodes modifies the host root physiology and facilitates the extensive damage by the fungus (Maria et al., 1998). Earlier reports of Jonathan et al. (1996), Senthamarai et al. (2008); Mallaiah et al. (2014), Sharf et al. (2014) and Meena et al. (2015) confirmed the synergistic effect of nematode-fungus interaction where they reported substantial reduction in growth and yield of the plants due to the interaction of nematodes and fungi which were fall in line with the present investigation.

Significant reduction in nematode population in the soil and root was observed in the sequential inoculation of fungus followed by nematodes and concomitant inoculation of the two pathogens. Infection of fungi in the plants reduced nematode population which might be due to the formation of mycelial mat over the roots which create unfavorable condition for the nematodes to enter into the roots and ultimately cause sex reversal in nematodes. i.e. female nematodes were converted into males during the unfavorable environmental condition and the male nematodes thus formed 
leave the root without feeding which creates reduction in the final nematode population in the roots. Report of Nagesh et al. (2006) supported the finding where they observed reduced gall index of $M$. incognita in tomato in the combined inoculation of nematodes and the fungal pathogens viz., Fusarium oxysporum, Paecilomyces lilacinus, Trichoderma harzianum and neem cake.

Modification in the physiological parameters of the plants has been noticed due to the nematode fungus interaction in the plants. Disruption of vascular tissues upon the infection of nematodes reduces the transportation of water and nutrients to the foliar systems which reduces the photosynthetic rates in the plants. Sequential inoculation of nematodes prior to the fungus subsequently reduced the chlorophyll level in the plants. Reports of Sharf et al. (2014) evidenced that sequential inoculation of $M$. incognita followed by the fungus, Pochonia chlamydosporia significantly reduced the chlorophyll content in Phaseolus vulgaris.

Increased protein and sugar content in bittergourd due to the infection of $M$. incognita was recorded by Gautam and Poddar (2014). Increased sugar level was observed on 30 days after inoculation of nematodes in the feeding cells of nematodes which coincides with the gall formation by the root knot nematodes. This confirmed supplementation of sugar for the growth of nematodes (Cabello et al., 2013). Increased level of proteins and sugars in the nematode infected plants might be due to high metabolic activity in the nematode infected tissues (Hoffmann et al., 2008; Nayak and Mohanty, 2010). Similar results have been recorded by Abbasi et al. (2008) in Okra and Brinjal. Thus sugar and proteins proved to play a major role in the pathogenecity of the nematodes.

Increased nutrient contents (amino acids, proteins and lipids) were observed in the parenchyma cells adjacent to the nematode feeding site. Root knot nematode maintain these cells in a perpetuate juvenile state with repeated nuclear division without cytoplasmic division (Huang and Maggenti, 1969). This state of parenchyma cells in the nematode infected plants aid in the successful penetration and establishment of Fusarium in the xylem vessels (Owens and Specht, 1966). Thus, nutrient enriched nematode infected cells were found to increase the growth of Fusarium hyphae than non infected roots.

Metabolically active plant cells were observed about four weeks after nematode infection which contain more concentration of photosynthate elements and increase the predisposing capacity of the nematodes to fungus. This results in the synergistic interaction between the two pathogens and increase the wilt severity in the plants.

The above reports clearly indicate that presence of nematodes increase the entry, infection and wilt severity of the fungus in the plant cells. Interaction of the two pathogens even modifies the composition of biochemical components in the plants to favour the growth and development of the pathogens. 


\section{CONCLUSION}

The above investigations clearly explain the relation between nematode and fungus and their role in causing the disease in carnation. The above study reported that the nematode, M. incognita acts as predisposing agent for the infestation of F.oxysporum and their combined infestation reduced the growth and yield parameters of the plant and significantly modified the biochemical components in the plant. Hence, nematode-fungus interaction should be given emphasis while formulating the management strategies for the effective management of the two pathogens.

\section{ACKNOWLEDGEMENT}

Authors thank Department of Biotechnology, Government of India for providing the financial support to carry out the research work.

\section{REFERENCES}

Abbasi, M. W., Ahmed, N., Zaki, M. J. and Shaukat, S. S. 2008. Effect of Barleria acanthoides Vahl. on root-knot nematode infection and growth of infected okra and brinjal plants. Pakistan Journal of Botany, 40: 2193-2198

Cabello, S., Lorenz, C., Crespo, S., Cabrera, J., Ludwig, R., Escobar, C. and Hofmann, J. 2013. Altered sucrose synthase and invertase expression affects the local and systemic sugar metabolism of nematode infected Arabidopsis thaliana plants. Journal of Experimental Botany, 2-12, doi:10.1093/jxb/ert359

Gautam, S. K. and Poddar, A. N. 2014. Study on protein and sugar content in Meloidogyne incognita infested roots of bitter gourd. International Journal of Current Microbiology and Applied Sciences, 3(5): 470-478

Gomez, K. A. and Gomez, A. A. 1984. Statistical procedure for agricultural research. John wiley and sons, New York

Hoffmann, J., Szakasits, D., BloChl, A., Sobczak, M., Daxbo, C.K., Horvath,S., Golinowski, W., Bohlmann, H. and Grundler, F. M. W. 2008. Starch serves as carbohydrate storage in nematode-induced syncytia. Plant Physiology, 146: 228-235

Huang, C. S. and Maggenti, A. R. 1969. Wall modifications in developing giant cells of Vicia faba and Cucumis sativus induced by root-knot nematode, Meloidogyne javanica. Phytopathology, 59:931-37

Jonathan, E. I. and Gajendran, G. 1998. Interaction of Meloidogyne incognita and Fusarium oxysporum f.sp.cubense on banana. Nematologia Mediterranea, 26: 9-11

Jonathan, E. I., Sivakumar, M. and Padmanabhan, D. 1996. Interaction of Meloidogyne incognita and Phytophthora palmivora on betelvine. Nematalogia Mediterranea, 24(2):341-343

Mai, W. F. and Abaw, G. S. 1987. Interactions among root-knot nematodes and Fusarium wilt fungi on host plants. Annual Review of Phytopathology, 25: 317-338 
Mahalakshmi, P. and Raja, Y. I. 2013. Biocontrol potential of Trichoderma species against wilt disease of carnation (Dianthus caryophyllus L.) caused by Fusarium oxysporum f.sp.dianthi. Journal of Biopesticides, 6(1): 32-36

Mallaiah, B., Muthamilan, M., Prabhu, S., and Ananthan, R. 2014. Studies on interaction of nematode, Pratylenchus delattrei and fungal pathogen, Fusarium incarnatum associated with crossandra wilt in Tamil Nadu, India. Current Biotica, 8(2): 157-164

Maria,C. P., Juan, M. A. and Jimenez-Diaz N. C. R.1998. Interactions of Pratylenchus thornei and Fusarium oxysporum f. sp. ciceris on chickpea. Phytopathology, 88(8): 828 - 836

Masse, D., Pate, E., Ndiaye-Faye, N. and Cadet, P. 2002. Effect of fallow improvement on the nematode community in the Sudanian region of Senegal. European Journal of Soil Biology, 38, 205-211

Meena, S. K., Ramyabharathi, S. A., Raguchander, T. and Jonathan, E. I. 2015. Meloidogyne incognita and Fusarium oxysporum interaction in Gerbera. African Journal of Microbiology Research, 9(18): 1281-1285

Nagesh, M., Hussaini, S. S., Ramanujam, B. and Chidanandaswamy, S. 2006. Management of Meloidogyne incognita and Fusarium oxysporum f.sp. lycopersici wilt complex using antagonistic fungi in tomato. Nematologia mediterranea, 34: 63-68

Nayak, D. K. and Mohanty, K. C. 2010. Biochemical changes in brinjal induced by root-knot nematode, Meloidogyne incognita. Indian Journal of Nematology, 40(1): 43-47

Owens, R. G. and Specht, H. N. 1966. Biochemical alterations induced in host tissues by rootknot nematodes. Boyce Thompson Institute Contribution, 23: 181-98

Sharf, R., Shiekh, S., Syed, S., Akhtar, A. and Robab, M. I. 2014. Interaction between Meloidogyne incognita and Pochonia chlamydosporia and their effects on the growth of Phaseolus vulgaris. Archives of Phytopathology and Plant Protection, 47 (5): 622630

Sokal, R. R. and Rohlf, F. J. 1995. Biometry: the principles and practice of statistics in biological research, 3rd ed. Freeman: New York

Senthamarai, M., Poornima, K., Subramanian, S., and Sudheer, M. J. 2008. Nematode-fungal disease complex involving Meloidogyne incognita and Macrophomina phaseolina on medicinal coleus, Coleus forskohlii Briq. Indian Journal of Nematology, 38(1): 30-33 